\title{
CONTROL BY LICENSING OVER ENTRY INTO THE MARKET
}

\author{
Irwin W. Silverman* $\quad$ L. T. BenNetT, JR. $\dagger$ Irvin LechiltrR $\dagger$
}

Much has been said and written concerning the weaknesses of the distributive processes in America. Undoubtedly, economic forces are at play which clog these processes and thereby militate against the efficient functioning of our capitalistic society. That some of these forces are aided and abetted by ill-advised legislation presents, on its face, a sound premise. Legislation inspired by a sincere and conscientious effort to avoid chaos or collapse of our industrial structure may be just as deadly. Whatever be the objectives of these measures, there is today, under governmental paternalism, an ever-growing mass of restrictive legislation operating to close the avenues of entrepreneurship to untold numbers who might otherwise be engaged in productive activity.

To criticize or evaluate motives back of this legislation is not the purpose of this paper. That licensing legislation is restrictive no one will deny. That the state must exercise some degree of control over persons and products in the field of commercial activity is also generally conceded. But, whether such restrictive measures are of benefit to the public and are essential to a more orderly economic society is highly problematical. In the alleged interest of the consumer and defended by doctrines couched in such hackneyed phrases as police power, public health, and public welfare, a mushrooming of legislation has spread designed to effectuate governmental supervision and control through licensing over many types of trades, businesses and occupations. Among those now embraced are barbers, plumbers, dry cleaners, watchmakers, tailors, food dealers, and bakers. And, of late, the state legislatures have shown a distinct tendency toward expanding this concept of licensing to include the regulation of product as well as personal competition.

The National Industrial Recovery Act unquestionably provided a temporary stimulus for both industrial and commodity types of control through licensing legislation. Its invalidation by the Supreme Court of the United States ${ }^{1}$ did not serve, apparently, to innoculate the patient against recurring attacks in modified

- Ph.B., 1930, Dr. Law, 1932, University of Chicago. Foreign Law Section, Law Library of Congress; formerly Chief Attorney, Marketing Laws Survey. Member, Illinois Bar.

† B.A., 1937, LL.B., 1936, LL.M., 1939, George Washington University. Chief Attorney, Marketing Laws Survey. Member, District of Columbia and Michigan Bars.

if A.B., 1932, University of Nebraska; J.D., 1937, George Washington University. Chief Administrative Attorney, Marketing Laws Survey. Member, District of Columbia and Nebraska Bars.

${ }^{2}$ Schecter Poultry Corp. v. United States, 295 U. S. 495 (I935). 
form. The National Automobile Dealers Association, for example, has been trying to secure the blessing of the Federal Trade Commission for a plan designed to establish a little NRA for the automobile industry. ${ }^{2}$ Milk control legislation, also, embodies a policy of strict control of competition. The New York milk control act furnishes an excellent illustration. By its terms and under its authority the licensing of dealers going into business after June $x$, I939, is forbidden, unless the regulatory board is satisfied that the issuance of the license is in the public interest. ${ }^{3}$ In two states, at least, bills have been introduced but not passed which would limit the number of automobile dealers. ${ }^{4}$ Much the same effect is achieved by licensing legislation which requires barbers to have completed a course in histology; plumbers to have had ten years experience or a degree in science from an accredited college; and photographers to be of good moral character and of sound financial integrity. These illustrations might be multiplied a hundredfold.

Just how far a state may go in controlling competitive practices by licensing or otherwise is at the present time highly conjectural. "Business affected with a public interest" may mean one thing under the doctrine of the Nebbia case ${ }^{5}$ and another under the doctrine of the Liebmann case. ${ }^{6}$ Again, the term may now be obsolete. One thing, however, seems clear; this type of licensing legislation is strikingly comparable to the "convenience and necessity" theory of governmental control as applied to public utilities. If the trend toward such legislation continues it may well be asked what is to become of individual enterprise. Are we to look forward to everincreasing restrictions on the right of the individual to enter a business of his own choosing? What are the limits of legitimate licensing legislation?

These problems can be determined only in terms of the effect and extent of legislative control, which in turn must revolve around one's basic philosophy as to the underlying objectives of government. What belongs within the province of proper legislative regulation may mean one thing to one group of men and quite another thing to another. Although to each, government is the means of achieving the greatest good for the greatest number, the fundamental struggle between the two groups centers around more and more laissez faire as opposed to more and more governmental supervision. To the former group, too much government inveighs regimentation, dictatorship or cartelization. To the latter, the rules of fair play may be more effectively controlled through governmental umpireship rather than through a self-disciplinary type of control. It is not within the scope of this discussion to attempt to say which of the two concepts is to prevail or which can be offered as a panacea to cure the ills of this troubled world. It is, however, our purpose to point out certain types of legislative restrictions which may operate for or against the achievement of a sounder economy.

\footnotetext{
${ }^{2}$ Fed. Trade Comm. Report on the Motor Vehicle Industry, H. R. Doc. No. 468, 76th Cong., Ist Sess. (1939) 367-368.

N. Y. AGRic. \& MARKETs LAw, art. 2I, \$258c.

- Note, Legislative Succor for the Motor Car Dealer (1939) 5 Ongo ST. L. J. 377.

¿ Nebbia v. New York, 29r U. S. 502 (1934).

- New State Ice Co. v. Liebmann, 285 U. S. 262 (I932).
} 
Beginning with a few simple licensing statutes in the earliest history of this country, there has evolved a series of progressive restrictions in governmental control of business until today even price-fixing is rather commonplace. Since the turn of the century, state licensing legislation in some form has encompassed virtually every conceivable type of profession, industry, business, trade and occupation. ${ }^{7}$ In addition, thousands of municipal ordinances now establish licensing requirements, to say nothing of the numerous limitations imposed upon various callings by villages, townships, counties, park districts, school districts, sanitary districts and other subdivisions of state governments. The Federal Government, too, has set up countless instances of licensing supervision. ${ }^{8}$

Generally speaking, until recent years three broad types of business licensing statutes were commonly employed. In the first classification may be placed licensing for revenue by states and municipalities levying a tax on the privilege of doing business. Secondly, there has been a plethora of licensing legislation for the avowed purpose of protecting public health or safety. Included in this category have been building contractors of various types, restaurants, barber and beauty shops, sellers of firearms and explosives, narcotics, liquor and milk and dairy products. The third classification takes the form of licensing or chartering utility services such as power, light, gas, water, transportation, communications, etc., where regulation is necessary because of the monopolistic nature of the business. Only recently has there appeared a fourth type of licensing legislation designed, as above emphasized, to effectuate the regulation of competitive practises and price policies.

For the purpose of examining the "barrier" implications of licensing legislation, this paper will attempt a breakdown of licensing legislation according to the restrictions imposed upon selected types of business enterprise. Certain types of these statutes clearly operate as barriers within the marketing process. The cumulative effect of others may be equally burdensome. An examination of these and their effects on different types of businesses can be made by dividing them into several categories. Two main classifications conveniently serve this purpose. The first involves the relations of persons to the state and includes licensing per se; restrictions as to qualifications, character and fitness; and certain other conditions precedent and subsequent to obtaining and retaining a license to engage in a business, trade or occupation. The second classification involves not only the relation of persons to the state, but more directly the relationship of those in the same business or trade to each other. As such it includes functional limitations; limitations as to the hours or days during which business may be conducted; limitations in the location of a business; and the price-fixing provisions within different types of enterprise.

\footnotetext{
${ }^{7}$ See, e.g., Index of N. C. Code (I939) pp. 3143-3145.

${ }^{8}$ Koons, Growth of Federal Licensing (1936) 24 GEo. L. J. 293. Municipal activity is covered by McIntire and Rhyne, Municipal Legislative Barriers to a Free Market, infra this issue.
} 


\section{Licensing Per Se}

\section{Relations of Persons to the State}

The right of the individual to enter into and engage in the business, trade or occupation of his choice was in the earliest history of this country considered to be a natural and absolute right. Governmental interference with that right was viewed with grave suspicion by the courts. For that matter, legislative branches of state government showed little disposition to interfere with the unrestricted functioning of individual enterprise. The system of licensing businesses, trades and occupations was confined to relatively few pursuits. Thus in Nebraska, in 188r, the only licensing legislation in effect was that applicable to peddlers, liquor sales and sales of real estate. ${ }^{9}$

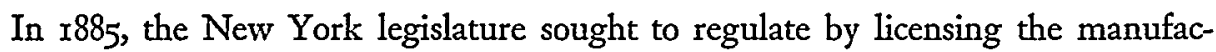
ture of cigars in the home. The court was shocked beyond measure by such legislative impertinence. In holding the statute repugnant to the fundamental rights of man, the language of the court clearly reveals the prevalent inhibitions of the time against governmental interference with private initiative: $:^{10}$

Such legislation may invoke one class of rights today and another tomorrow, and if it can be sanctioned under the Constitution, while far removed in time, we will not be far away in practical statesmanship from those ages when governmental prefects supervised the building of houses, the rearing of cattle, the sowing of seed and the reaping of grain, and governmental ordinances regulated the movement and labor of artisans, the rate of wages, the price of food, the diet and clothing of the peoples, and a large range of other affairs long since in all civilized lands regarded as outside of governmental functions. Such governmental interferences disturb the normal adjustments of the social fabric, and usually derange the delicate and complicated machinery of industry and cause a score of ills while attempting the removal of one.

Today, licensing per se, or a licensing law enacted under the state's revenueraising powers providing for merely a two, three or five dollar fee, without more, is generally not open to judicial question. However, the cumulative effect of such legislation, especially as experienced by businesses or industries operating in several states, counties, or cities, may be open to serious economic objections.

\section{Qualifications, Character and Fitness Requirements}

Rigid requirements as to qualifications, character and fitness undoubtedly are justified as conditions precedent to the issuance of a license in certain businesses and professions. No exception can be taken to statutes which demand high standards of lawyers, physicians, dentists, nurses and accountants. Knowledge peculiar to such callings is achieved only after thorough education. Their dealings involve a peculiarly personal trust relationship to their clientele and the public must necessarily place complete reliance upon their individual knowledge, judgment and skill. Similar requirements are justifiably applied to the so-called quasi-professional groups, those including osteopaths, neuropaths, chiropodists, veterinarians, mid-

\footnotetext{
- See Index of Neb. Comp. Stat. (1881) p. 783. ${ }^{20}$ In re Jacobs, 98 N. Y. 98, 114 (1885).
} 
wives, and similar occupations. The courts have shown a clear disposition to sustain licensing requirements of qualifications, character and fitness as applied to such groups, either because of their relationship of trust or because of the primary importance of public health.

These particular requirements, however, when applied to the ordinary trades of barbering, cosmetology, plumbing, building, watchmaking, or photography, frequently assume a more onerous aspect. At least a potential danger arises that many an honest, conscientious man or woman will be deprived of earning a livelihood. Such statutes may readily operate to restrict the number of persons who may engage in a particular occupation, and also lead, in some degree, to the control of competition and price. Whether this result is desirable or undesirable depends upon one's views with relation to our economic society. In any case, an examination of a few statutes establishing these requirements for certain occupations may be profitable.

The licensing of barbers furnishes an excellent illustration. Applicants for a barber's license must have educational qualifications ranging from a knowledge of the English language ${ }^{11}$ or a grammar school education ${ }^{12}$ to at least two years of high school..$^{13}$ In addition, they may be required to have completed a course of instruction in a licensed or approved school of barbering, the instruction to include a certain number of credit hours in some or all of the following subjects: scientific fundamentals of barbering; hygiene; bacteriology; histology of the hair, skin, nails, muscles, nerves; structure of the head, face and neck; elementary chemistry relating to sterilization and antiseptics; diseases of the skin, hair, glands and nails; haircutting; shaving; arranging, dressing, coloring, bleaching and tinting of the hair. The applicant, furthermore, must have served an apprenticeship of from six months ${ }^{14}$ to three years, ${ }^{15}$ and may also be required to pass satisfactorily an oral, written and practical examination as given by Boards of Barber Examiners, whose qualifications generally are not adequately defined and whose powers, in many instances, are so broad and whose discretion is so wide that they may be exercised in an arbitrary and unreasonable manner. Many such statutes have received judicial sanction on the ground of compatability with public health and welfare. ${ }^{10}$ Illustrative of the view taken by many courts is the language of the highest court of North Carolina used in upholding that state's barbering law: ${ }^{17}$

${ }^{11}$ Okza. Stat. Ann. (1938) tit. 59, $\$ 76$.

${ }^{22}$ OHTo CODE ANN. (Throckmorton, 1940) \$1081-13.

${ }^{13} \mathrm{Ky}$. Laws Sp. Sess. 1938, c. 44, \$ro.

${ }^{24}$ Mich. Comp, StaT. (Mason, Supp. 1937) $\$ 8700-2$ (rob).

${ }^{25}$ Conn. Gen. Stat. (Supp. 1935) SIr94c.

${ }^{10}$ People v. Stiegler, I60 Misc. 463, 290 N. Y. Supp. 732 (1936); Clark v. State, x69 Miss. 369, 152 So. 820 (1934); State v. Ross, 185 S. C. 472,194 S. E. 439 (1937); State v. Blocker, 176 Ga. x25, x67 S. E. 298 (1933); Mundell v. Graph, 62 S. D. 63I, 256 N. W. x2I (1934); State v. Nolan, I6I Tenn. 293, 30 S. W. (2d) 6or (1930); Gerard v. Smith, 52 S. W. (2d) 347 (Tex. Civ. App. 1932); State v. Wester, 135 Wash. 32, 236 Pac. 790 (1925); State v. Briggs, 45 Ore. 366, 77 Pac. 750 (1904); State v. Zeno, 79 Minn. 80, 8r N. W. 748 (1900).

${ }^{27}$ State v. Lockey, 198 N. C. $55 x, 557,152$ S. E. 693,696 (1930), upholding the validity of the Barber's Code, N. C. Code (Michie, 1939) \$\$5003 et seq. For similar laws see Car. Gen. LAws (Deering, 1937) act 665; W. VA. Code (1937) \$\$1409(39) et seq.; MD. Code ANn. (Flack, 1939) art. $43, \$ \$ 304$ et seq. 
We think the regulations reasonable and the whole act in the interest of skill, proficiency, health and sanitation; and brings the barber and barber shop up to a high standard for the protection of the health of the public.

In a few states, the courts have invalidated this type of legislation. The Maryland Barber's Code, for instance, was found to be something more than a measure designed to safeguard the public health: ${ }^{18}$

This trade is neither highly technical nor exceptionally difficult, and its nature is understood by persons, generally; the many regulations found in this act seem to be unnecessary and unreasonable in safeguarding public health or security.... This trade has long been recognized; it is one that may not be destroyed, and in which people desiring to engage may not be arbitrarily prevented.

In concluding, the court observed that the obvious purpose of the act was not to protect the public health but to restrict the number of persons entering the trade; and, under the principle "that the police powers of a state could be used only for the welfare of the general public," this attempt to foster a monopoly was found to be repugnant to the Fourteenth Amendment. ${ }^{19}$

The barbering trade offers but one illustration of ordinary occupations which may be subjected to extensive licensing requirements by way of qualifications, character and fitness. A New York statute requires applicants for licenses as master plumbers "to have had not less than ten years experience in the plumbing industry in the United States, except that three years experience in the plumbing industry shall be sufficient together with a technical degree in engineering from a college or university approved by the Regents of the University of the State of New York." ${ }^{20}$ In a challenge of the validity of this statute, the petitioner's charge that such "regulation of the right of new people to engage in competition as master plumbers is a Fascist method of industrial control which should be allowed no headway in our Democracy," was answered with the judicial assertion that the statute "merely safeguards" the public interest by providing necessary experience and training as to the required qualifications. With respect to the provision of the act authorizing the licensing authority to call upon the plumbing industry for assistance in the preparation, conduct and rating of the practical, oral and written examinations of persons seeking a plumber's license, the same court said without reservation: ${ }^{21}$

It is most natural and indeed desirable that this Commission be given the right to obtain the views of the plumbing industry in connection with the determination of the proper qualifications of a master plumber.

${ }^{28}$ Schneider v. Duer, 170 Md. 326, 332, I84 Atl. 914, 917 (1936).

${ }^{10}$ Compare the language in People v. Logan, 284 Ill. 83, 86, Ir9 N. E. 913, 914 (19I8): "Three years seems like a long time for learning the trade of a barber, but we cannot say that it is so unreasonably long as to constitute an unreasonable restriction upon the right to engage in the trade."

${ }^{20}$ N. Y. Laws 1936 , c. 6 ro.

${ }^{21}$ Benedetto v. Kern, I67 Misc. $831,837,4$ N. Y. S. (2d) 844,850 (r938), affd by Mem. Dec., 255 App. Div. 753, 7 N. Y. S. (2d) 227 (1938). 
No consideration was given to the implications of limiting competition by such means. A more realistic view is presented by the dissent in an earlier New York case of the same judicial temperament: ${ }^{22}$

Taking the act [an earlier similar act] as a whole, it would seem quite apparent that its purpose is to enable the employing plumbers to create a sort of guild or body among themselves into which no one is permitted to enter excepting as he may pass an examination, the requisites of which are not stated, and where his success or failure is to be determined by a Board of which some of their own number are members. . . . It is difficult to see the least resemblance to health regulation in all this.

As late as I925, an Arkansas court, conceding that its decision was against the weight of authority, refused to uphold a plumbers' licensing ordinance because there was no relation to health regulation in requiring one to become a member of a "favored body" before engaging in a trade..$^{23}$

The changing conceptions of the courts in relation to this problem may best be portrayed by two Washington decisions. In the earlier of the two cases, the court of that state said: ${ }^{24}$

We are not permitted to inquire into the motive of the legislature, and yet, why should a court blindly declare that the public health is involved when all the rest of mankind know full well that the control of the plumbing business by the Board and its licensees is the sole end in view.

Twenty-four years later the same court made this very significant statement: ${ }^{25}$

Courts do not act upon evidence as to what is and what is not so designed to promote the public welfare, but, to the contrary, every such act is presumed to be in the interest of the public welfare if a state of facts might possibly exist which would justify it.

The tide is running toward a more integrated control of trades and professions and the courts show little disposition to check it. Undoubtedly there are advantages in such restrictive legislation, even to the consumer, but it may also lead to the disadvantages of the old mercantilist system which it so closely resembles.

An applicant for a contractor's license in New Mexico must submit a complete statement of the nature of his business and his experience. He must be of good reputation and must never have lost a license by revocation or suspension on any ground that would preclude his being granted a license in New Mexico. ${ }^{20}$ The Michigan contractors' licensing law for Detroit $^{27}$ requires that the written examination must show

... a fair knowledge of the English language including reading, writing, spelling and elementary arithmetic, and an ability to read and interpret plans and specifications, the

${ }^{22}$ People v. Warden of City Prison, 144 N. Y. 529, 543, 39 N. E. 686, 690 (1895).

${ }^{23}$ Replogle v. City of Little Rock, I66 Ark. 617, 267 S. W. 353 (1925).

${ }^{34}$ Richey v. Smith, 42 Wash. 237, 249, 84 Pac. $85 x, 854$ (1906).

${ }^{25}$ City of Tacoma v. Fox, 158 Wash. 325, 331, 290 Pac. roro, rorz (1930):

${ }^{20}$ N. M. Laws 1939, c. 197. The Comptroller General of the United States has held that the United States Government was not precluded from accepting bids from New Mexico contractors not licensed under this law. (I940) I9 OP. CoMpt. GeN. 735.

${ }^{37}$ Mich. Laws 1939, No. 311, \$8690-25. 
obligations of a residential building contractor to the public and his principal, and the provisions of the Michigan statute relating to the regulating and licensing of residential building contractors.

This law carries, also, the curious provision that the required recommendations by two citizens of the state must be accompanied by a "legal description of at least one parcel of real estate" owned by the persons recommending the applicant. Thus it is made certain that local property owners control the induction of new entrants into the trade.

In Maryland a statute was invalidated which set up machinery for the purpose "of issuing licenses and examining into the qualifications and capabilities of all persons engaging in or desiring to engage in the business of paper-hanging."28 The court declared the act to be an unfair and unjust interference with the "common right of engaging in an ordinary trade." Such a legislative measure, said the court, had no substantial relation to the public health or safety. ${ }^{29}$

On the other hand, a North Carolina statute providing that every person desiring to engage in the practice of photography must first fully satisfy a Board of Photographic Examiners as to his "technical qualifications, business record and moral character,"30 was sustained on the ground that photography requires skill and involves the use of chemicals and other combustible materials to such a degree that the public interest is sufficient to warrant adoption of the act. ${ }^{31}$

There has as yet been no determination of the legality of the Wisconsin watchmaker's statute which provides that no person can engage in the trade of watchmaking, watch repairing or watch reconditioning without first satisfying a Board of Watchmakers as to his theoretical knowledge of watch construction as well as to his technical ability in handling tools and certain other mechanical devices. ${ }^{32}$

Recently a new type of licensing legislation directed at automobile dealers has been adopted in four states. ${ }^{33}$ Because this legislation was designed to cope with the chaotic economic situation existing among automobile retailers, it will be discussed later. Suffice it to say here that under all four statutes, a license may be denied upon proof of unfitness or bad business repute of the applicant.

It should be observed that in most of these statutes, rather wide discretionary authority is placed in the hands of an administrative agency, frequently composed of members of the industry, particularly for the purpose of determining character

${ }^{28}$ Md. Laws 1935 , c. 377 .

${ }^{20}$ Dasch v. Jackson, I70 Md. 251, I83 Atl. 534 (1936).

${ }^{30}$ N. C. CoDE ANn. (Michic, r939) \$\$7007 et seq.

${ }^{31}$ State v. Lawrence, 213 N. C. 674 , 197 S. E. 586 (1938), cert. denied, 305 U. S. 638 (1938).

32 WIs. STAT. (I939) c. I25.

${ }^{33}$ Wis. Stat. (1939) \$2r8.or; Ohro Code ANN. (Throckmorton, I940) \$6302-I; Neb. Comp. Stat. (Supp. r939) \$60-90I; Iowa Code (1939) \$5039.or. Pennsylvania adopted a similar act, PA. STAT. ANs. (Purdon, 1937) §130r, which was invalidated before it went into effect. Heinel Motors, Inc. v. Teefy, 295 Commonwealth Docket (Dauphin County Ct. 1937). Two Texas cities, Dallas and Houston, have licensing ordinances, set up under Tex. Laws x937, tit. 28, c. 6, which achieve the same type of control. Motor Vehicle Dealer Licensing Laws in Force (Auto Mfters. Ass'n, I938). 
and fitness. Such terms as "bad business repute," "unfitness," "competent and trustworthy," etc., are "weasel" words subject to varying interpretations. Irrespective of the merits of allowing a wide range of latitude in administrative control, it is apparent that discretionary power as indefinite as that illustrated in some of these statutes is potentially open to abuse especially in cases where members of a board may be interested in restricting the number of their competitors to the absolute minimum. It is, of course, true that frequently the statutes provide for review by a court of competent jurisdiction. But such safeguards do not remove the infirmity attaching to an unlawful delegation of authority.

"Bad business repute" and "good character and reputation" have received judicial sanction by the Supreme Court of the United States as terms sufficiently definite to satisfy the Fourteenth Amendment. ${ }^{34}$ There are state court decisions, however, which have disapproved the delegation of authority to determine "competent and trustworthy,"35 "unprofessional conduct,"36 and experience, ability and general reputation for integrity. ${ }^{37}$ Certain standards such as "good moral character" and "unfair competition," have, through years of definition, come to have a comparatively

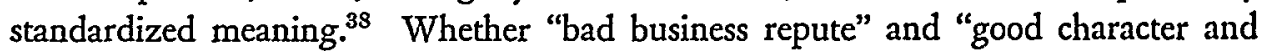
reputation" fall within this latter category may be open to some doubt. In any event, the discretion allowed the administrator in making such determinations may conceivably result in his limiting the number of persons who may engage in a particular business in a particular state.

\section{Other Conditions Precedent}

Applicants for licenses to participate in various business activities may also be required to meet burdensome bonding or financial requirements. Here, again, such requirements may serve an excellent purpose when applied to certain businesses. At the same time, these statutory provisions may result in closing the avenues of business to small operators, many of whom are unable, because of lack of capital, to meet rigid prerequisites of this character.

An illustration of this type of restrictive licensing is found in the Louisiana commodity control statute requiring all applicants for wholesale farm produce dealers licenses to deposit with the Commissioner of Agriculture a $\$ 2,000$ bond to insure faithful performance and "to secure the payment of all moneys or accounts owed by the dealer in farm produce to any person, firm, exchange, corporation or association arising out of the conduct of the business of such dealers in farm produce."30 This law is in many respects similar to the bonding requirements contained in the 2I milk control acts as well as those contained in many of the other commodity

${ }^{34}$ Hall v. Geiger-Jones Co., 242 U. S. 539 (1917); Gundling v. Chicago, 177 U. S. 183 (1900). Cf. Mutual Film Corporation v. Ohio Industrial Commission, 236 U. S. 230 (I915).

${ }^{35}$ Harmon v. State, 66 Ohio St. 249, 64 N. E. $\times 17$ (1902); Toledo v. Winters, 21 Ohio Dec. 171, Ir Ohio C. C. (N. S.) 577 (Igro).

${ }^{30}$ Mathews v. Murphy, 23 Ky. 750, 63 S. W. 785 (1901).

${ }^{37}$ People v. Beckman \& Co., 347 Ill. 92, x79 N. E. 435 (1932).

${ }^{38}$ Freund, Administrative Powers Over Persons and Property (1928) 276.

${ }^{\text {so }}$ La. Laws I932, act 237, as amended Laws 1934, act 176. 
control laws dealing with such articles as fruit, fuel and agricultural products. ${ }^{40}$ All of the statutes contain provisions requiring applicants, before licenses will issue, to produce financial statements and to satisfy fully the commissioners or members of the boards as to their financial position and integrity as well as to their possession of adequate and sufficient physical facilities and machinery properly to carry on and conduct their respective businesses. ${ }^{41}$

Building contractors frequently may be required by law to post a bond for the satisfactory performance of contracts. In many instances, a smali contractor may be precluded from bidding on construction projects owing to financial inability to meet this requirement of the licensing statute. Automobile dealers, under the newer type of licensing control mentioned above, must meet various financial requirements. Wisconsin, Ohio and Iowa specifically require the applicant to submit a financial statement. $^{42}$

These automobile dealer statutes also serve to illustrate another restriction of this character which takes the form of limiting the number of persons who may engage in a particular business, thus drawing a parallel to the "convenience and necessity" theory of licensing. Comparable also in this respect is the New York milk control act $^{43}$ which provides that the commissioner shall issue no license unless he is satisfied that "the issuance of the license will not tend to destroy competition in a market already adequately served, and that the issuance of the license is in the public interest"; and under no circumstances can the commissioner issue a milk dealer's license to any person not now engaged in the busiriess as a milk dealer.

Financial and bonding requirements for licenses have been generally sustained by the courts as a valid exercise of the state's police power. A New York court went so far as to restrain a milk dealer from buying milk from producers for resale without executing a bond or furnishing security as required by the act, notwithstanding the fact that the producers with whom the dealer had regularly dealt for many years did not want such protection. ${ }^{44}$ On the other hand, a Michigan statute which called for the filing of a $\$ \mathrm{I}, 000$ bond by a contractor suggested to the court of that state too much paternalism in ordinary business relations and was accordingly invalidated. ${ }^{45}$

${ }^{10}$ See State Milk \& Dairy Legislation (W.P.A. Marketing Laws Survey, 1939); see also Tex. Stat. (Vernon, Supp. I938) art. 576a (citrus fruit); CAL. GeN. LAws (Deering, I937) act 2666 (foodstuffs); Colo. Stat. Ann. (Michie, Supp. I939) c. Iro; Conn. Gen. Stat. (r930) \$2306; N. M. Stat. ANN. (Courtright, 1929) \$\$24-IOI to 24-IO9 (coal, oil and fuel); Cat. AGric. Code (Deering, Supp. I939) \$\$300.I3 et seq.; Gs. Code ANN. (Park et al., x936) \$\$5.21 I et seq.; Idaho Laws I935, c. II3 (agricultural commodities).

${ }^{41}$ Fla. Comp. Gen. Laws (Supp. 1940) $\$ 3219(46)(2,3,4)$; Ind. Stat. AnN. (Burns, Supp. r939) \$15-1707(A); La. Laws 1932, act 237, as amended Laws 1934, act r76; N. Y. AGRIC. \& MARkeTs Law, art. 21, \$258c; PA. Stat. ANN. (Purdon, Supp. 1939) §700j-403; Wis. Stat. (1939) \$100.03.

${ }^{2}$ Note 33 , supra.

${ }^{3}$ N. Y. Agric. \& Markets Law, art. 2I, \$258c.

"Ten Eyck v. Eastern Farm Products, 160 Misc. 402, 290 N. Y. Supp. 475 (I936), aff'd, 249 App. Div. 89r, 292 N. Y. Supp. 787 (1937). See also, Ex parte Welling, 27 Cal. App. (2d) 367,80 P. (2d) 1027 (1938); Com. ex rel. Margiotti v. Ortwein, 132 Pa. Super. I66, 220 Atl. 859 (1938).

${ }^{45}$ Harrigan \& Reid Co. v. Burton, 224 Mich. 564, I95 N. W. 60 (1923); but see City of Milwaukee v. Rissling, 184 Wis. $51 \%$, 199 N. W. 61 (1924). 
This type of statute, again, vests a great amount of discretionary authority in an administrative board and some of these laws have been invalidated on the ground of improper delegation. The Louisiana court in declaring its produce act ${ }^{46}$ invalid held ${ }^{47}$ that a statute

... which undertakes to regulate a lawful business or occupation by conferring upon a designated officer, or commission, or board, the authority, within his or its judgment or ["sound"] discretion, to grant or to withhold a license or permit to engage in the business or occupation, and which does not prescribe a rule or standard to which all persons similarly situated may conform, constitutes a denial of the equal protection of the laws.

A more current view, however, is expressed in the words of the New York Court of Appeals in upholding the validity of a similar provision in the New York milk control law: $:^{48}$

The condition that the Commissioner shall be satisfied that the applicant is "qualified by character, experience, financial responsibility and equipment to properly conduct the proposed business" is not fairly open to that criticism. "True, the Legislature has not attempted to create a rule of thumb by which a man's character, experience, financial responsibility and equipment may be measured. It is difficult to conceive of a rule of thumb which could be formulated. None the less, it has created a standard by which such qualifications can be measured. They must be sufficient "to properly conduct the proposed business." All that is left to the Commissioner is to weigh the evidence and determine the fact.

\section{Conditions Subsequent}

Closely related to conditions precedent are conditions subsequent. In order to engage in trades or occupations of their choice, applicants for licenses must not only comply with many rigid restrictions for permission to enter into a particular occupation, but must satisfy many limitations equally burdensome in order to remain in that occupation. Such subsequent restrictions may be of a negative or a positive character.

Restrictions of a negative character take various forms. One of the most important is the type of limitation which provides for the suspension or revocation of a permit for failure to comply with fair trade practices prescribed for a particular trade or occupation. Unfair practices provisions usually prohibit, among other things, "loss leader" sales, gifts or other selling practices that result in sales below cost. Such restrictions on sales may serve to protect the small businessman against unfair competitive practices directed against him by larger businesses of the same type as his. These provisions, however, are frequently coupled with others of an indefinite character, with wide discretionary authority to suspend or revolse licenses for violation. A small operator may find himself faced with a serious problem in

"Note 39, supra.

47 State v. Chisesi, 187 La. 675, 693, 175 So. 453, 459 (1937).

${ }^{48}$ Matter of Elite Dairy Products v. Ten Eyck, 27 I N. Y. 488, 495, 3 N. E. (2d) 606, 609 (x936) (italics supplied). See also, Matter of Crowley's Milk Co. v. 'Ten Eyck, 270 N. Y. 328, I N. E. (2d) I19 (1936); Sheffield Farms v. Ten Eyck, 252 App. Div. 825, 299 N. Y. Supp. 340 (1937); Highland Farms Dairy v. Agnew, 300 U. S. 608 (1937). 
this connection. Often the only way for him to meet the competition of his more powerful competitor is to sell at a slightly lower price or to offer certain other inducements to attract customers. Owing to lower operating costs, he may well be able to afford such concessions and still make a profit. Is he to be required to sell at the same price as his more elaborate competitor who must meet high rentals, large payrolls and high advertising costs? Under a legislative provision of this nature he is. This type of control is a far cry from the concept of individual enterprise.

By way of illustration, there are within this category restrictions directed against trade practices. Thus the Wisconsin watchmakers statute empowers the Board of Watchmakers to suspend or revoke a license when it is satisfied that the holder of a license is grossly incompetent, or is guilty of immoral or unethical conduct. Immoral or unethical conduct is defined ${ }^{49}$ as

conduct of a character likely to mislead, deceive or defraud the public; advertising of any character in which untruthful or misleading statements are made; advertising of prices on watch repairing, or the giving of watch glasses, crystals or of any other watch parts, gratis, or at less than cost, in order to advertise or increase the watch repair business. . .

The Wisconsin automobile dealers license law includes as a ground for revocation, engaging in "unconscionable or unfair trade practices"; these practices are defined to embrace the making of such consistent and material allowances on used car "trade-ins" over a period of time as would tend to affect competition adversely, demoralize the industry or injure consumers. ${ }^{50}$ In Nebraska, an automobile dealer's license may be suspended or revoked for the defrauding of customers; intentional publication of misleading or inaccurate advertising; violation of state or federal laws relating to fair or unfair trade practices; wilful or habitual allowance of excessive trade-ins for the purpose of lessening competition or destroying a competitor's business; violation of the antidiscrimination laws; discrimination between purchasers with respect to the furnishing of services or facilities or the granting of discounts or rebates. ${ }^{.1}$

Falling within this category of negative restrictions are also those which are primarily directed against the entry of the licensee's products or services into the market. While the purposes for which legislation of this character is enacted are in many instances laudable and essential for the protection of the public health, nevertheless, the total effect of all such restrictions may be so great that in operation the purposes for which they were enacted are defeated. The many state grading, labelling, quarantine and inspection laws are examples of this type of restriction. That milk should be rigidly inspected is not only desirable but imperative. Yet, remembering that each such inspection means a corresponding boost in the price the consumer will ultimately pay, it is questionable whether the public health requires an equally rigorous inspection of the same can of milk as it passes from

${ }^{10}$ WIS. Stat. (I939) c. 125.

${ }^{10}$ Id. c. $2 \times 8$.

${ }^{81}$ NEB. COMP. Stat. (Supp. 1939) \$60-901. 
milk shed area to milk shed area, from county to county and from state to state as is required by numerous state milk inspection laws.

Of the same character, and in operation having a similar effect, are the myriad of detailed and exacting restrictions imposed upon builders and contractors as respects foundations, outer-walls, floors, partitions, shafts, courts, stairways, halls, roofs, and skylights. Lumber, cement, steel, concrete and fixtures to be installed must meet equally rigid specifications under each of the building codes adopted by the states and under many more ordinances adopted by each of the municipalities within the states. That these measures bear a close relationship to public health and safety no one can deny. Not so clear, however, are the considerations of public health and safety that require by legislation in many cities the revocation or suspension of a contractor's license for installing in private homes plumbing fixtures of the same type and character as those which have been installed in the palatial structure housing the United States Department of Justice.52

A witness in testifying at the hearings before the Temporary National Economic Committee with respect to the legislative delays in removing many of the marketing barriers from the building and construction codes, said: ${ }^{.3}$

Naturally, when you have a building code where somebody has in the past set up for himself a special privilege, and that special privilege is being removed, he resents it; he is trying to keep his position ... and he uses influence of every kind that he can to persuade those that are in charge of adopting the code to keep the old privilege intact.

Thus, the Chicago Code, on advice of the plaster contractors and the building trades' union rather than upon the recommendations made by technical experts on the basis of scientific studies and surveys, still systematically favors the use of lathes and plaster over the use of plaster boards, insulation boards or hard fiber boards. ${ }^{\text {t4 }}$ And, for similar reasons, the New York building code requires I2 inch plaster walls that will withstand a fire test for 4 hours, while walls made of glass are required to withstand a fire test of only 5 minutes. ${ }^{65}$ These examples can be multiplied, but the whole question is best presented in the words of a member of the Temporary National Economic Committee: ${ }^{56}$ "I think we all agree that building codes are a distinct hindrance to the use of improved building materials."

Typical of restrictions against services is an ordinance adopted by the city of Roanoke, Virginia, ${ }^{57}$ regulating the practice of barbering. In addition to all of the other health measures in effect in the state and locally, providing for enforcement through fine and imprisonment of the many health and sanitary regulations covering all types of trades, businesses and occupations, this ordinance makes possible the suspension or revocation of a permit or license if the barber fails to, report to the health authorities the name and address of any employee engaged as a barber whom

${ }^{62}$ Arnotd, The Bottlenecks of Bustness (1940) 43.

${ }^{63}$ Hearings before the Temporary National Economic Committee, 76 th Cong., $2 d$ Sess. (1940) No. Ir, at 5327 .

${ }^{5}$ Edwards, Trade Barriers Created by Business (1940) I6 IND. L. J. 169, 173.

${ }^{85}$ T. N. E. C. Hearings, supra note $53 . \quad{ }^{80} \mathrm{Id}$. at 5335.

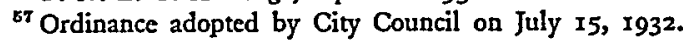


he knows or suspects to be suffering from an infectious disease, however slight; sterilize after each and every separate use thereof all razors, brushes, combs, scissors, tweezers and all other implements that may come in contact with the skin of a customer; use a freshly laundered towel, hair-gown or other cloth for each customer; change the head-rest of each barber's chair with a freshly laundered towel or clean sheet of paper before its new occupancy; wash his hands thoroughly with soap and hot water and rinse and immerse them in an approved disinfectant before attending any person; wear a freshly laundered (washable) outer coat when attending each customer. And in addition to other exacting health, sanitary, light, air and ventilation requirements, the barber may also be barred from engaging in the trade if he uses powder-puffs, sponges, neck-dusters, soap, shaving cups, finger bowls and all such other utensils in common with or for more than one person.

There are also other restrictions affecting the entry of products and services, but these are more in the nature of conditions precedent, conditioning $a b$ initio the entry of goods, commodities and services into the state market. These are the restrictions commonly referred to as interstate trade barriers, their purpose being not to limit functionally the marketing of products in intrastate and interurban commerceresidents and non-residents being treated alike-but to act as a geographic limitation to restrict the marketing of products and services coming from other states, to the advantage of local residents, products and businesses.

Finally, there are within this group of negative restrictions those which are directed against personal conduct, character and behavior, some of which are particularly difficult to enforce. In North Carolina, the Board of Tile Contractors is authorized to suspend or revoke a license when it is satisfied that the licensee is guilty "of gross negligence, incompetency or inefficiency in carrying on the business of tile contracting." Still more intricate are state laws which provide that a barber's license may be revoked on grounds of drunkenness, or habitual addiction to the use of drugs..$^{59}$ Some barbers are inclined to subject their patrons to a conversational barrage. Why not legislate against this baneful conduct also? Such legislation would be susceptible to enforcement with about the same degree of success. Who is to determine when a barber is drunk? May he get drunk after hours or is the sanctity of his own home to be violated? In North Carolina, a photographer may be prevented from earning a livelihood if he is found guilty of any crime, however trivial, so long as it involves his moral turpitude. ${ }^{60}$ In these instances the legislature would have done well to appropriate money for a morals squad to be attached to the office of the administrator of the act.

Of the affirmative type of conditions subsequent are the special industrial or occupational taxes, other than the general revenue-raising measures, imposed upon licensees for the privileges extended to them by the state of engaging in certain lines of business. In New Mexico, barber shops, dry-cleaners, beauty parlors and

\footnotetext{
${ }^{\text {zg }}$ N. C. Code ANn. (Michie, I939) $\$ \$ 5168$ (ggg)-(lll).

${ }^{60}$ See the statutory citations supra notes II-15.

${ }^{00}$ N. C. CODE ANN. (Michie, 1939) $\$ \$ 7007$ (I)-7007 (29).
} 
retail oil stations are required to pay annually a sum equal to two percent of their gross receipts for the franchise of doing business. ${ }^{61}$ A Louisiana statute provides for an annual privilege tax on all persons, individuals or corporate, engaged in the laundry and dry-cleaning business, except those persons who themselves actually perform manual labor in the plants. ${ }^{62}$ This exception was upheld where an individual operating under a trade name worked daily in his cleaning establishment, using his hands and machinery, even though. he was assisted by two men and a woman. ${ }^{63}$ But the exception was held not to apply to a laundry and dry-cleaning company employing labor, although the owners themselves did call for and deliver clothes for the business. ${ }^{64}$ The court in the latter case, basing its authority solely upon the decision of the Supreme Court of the United States in the Quong Wing case, ${ }^{06}$ held that a discrimination in favor of one who labors with his hands is not unreasonable or arbitrary. But the California statute involved in the Supreme Court determination, although somewhat similar, discriminated for an opposite purpose; large powerful steam laundries were to be protected by the discriminatory legislation against the encroachments upon their businesses by small Chinese hand laundries.

\section{Retation of Persons in Business to Each Other}

\section{Functional Limitations}

Conditions precedent and subsequent involve primarily the state on the one hand and, on the other, the persons seeking the right from the state to engage and remain in the business, trade or occupation of their choice. The remaining restrictions are of a more collateral character affecting not only the relationship of these persons to the state but the relationship of those in the same business to each other. First to be considered in this group are the functional limitations tending to restrict and delimit, in this age of over-specialization and occupational disintegration, the scope of individual activity within the occupational classifications. Among the functional limitations there are four types of restrictions: first, those which become restrictive through too narrow a definition of the sphere of the business, trade, or occupation; second, those which become restrictive because of too great a breadth of such a definition; third, those which restrict by separating knowledge and scientific learning from unlicensed management and control; and, fourth, those restrictions which are directed against the offering of incidental services.

Within the first type are such provisions as those contained in the milk control laws empowering their respective boards to attach such limitations to each license as they may deem necessary in restricting the licensee's sphere of activity. In New York, the licensee may be confined in his dealings to a single product or a single type of milk, such as surplus, fluid or dry milk, and may be confined to certain specific functional methods of production, handling, transportation, sales or dis-

\footnotetext{
${ }^{61}$ N. M. Laws r939, c. 94, 5r.

${ }^{62}$ LA. Gen. Stat. (Dart, I939)' $\$ 8612$ et seq.; see also LA. Const. (I921) Art. ro, $\$ 8$.

${ }^{63}$ State v. Chicago Hat Works, I74 La. 8r4; r41 So. 844 (1932).

${ }^{2}$ White Cleaners \& Dyers v. Hughes, 7 F. Supp. 1017 (W. D. La. 1934).

${ }^{\text {¿x }}$ Quong Wing v. Kirkendall, 223 U. S. 59 (1912).
} 
tribution. ${ }^{66}$ Also within this group are provisions like a Michigan law prohibiting other than registered pharmacists from selling epsom salts even though the salts comply with all pure food regulations and are sold in package form prepared by proper and duly licensed pharmaceutical laboratories; the laws in 39 states requiring one to obtain a registered pharmacist's certificate in order to sell iodine; the Indiana law providing that no one but a registered druggist may sell a bottle of witch-hazel; the laws in eight states prohibiting the sale of peroxide of hydrogen in places other than registered pharmacies; the New York statute to the effect that Ex-Lax may be sold only through pharmacies duly registered in the state; and the Illinois provision imposing a similar prohibition on the sale of bicarbonate of soda. ${ }^{67}$

Another type of restriction within this category of narrowly defined occupations is found in a Colorado statute providing that food may be served and sold for consumption only on premises licensed as restaurants. Restaurant is defined as ${ }^{68}$

an establishment provided with special space and accommodations where ... meals are habitually furnished to guests, or a place where food is prepared for human consumption . . . and whose principal business is the sale of meals and in which room nothing is sold excepting meals, food, drink and tobaccos. Any establishment connected with any business whatsoever ... . where any business is conducted excepting the sale of meals, foods, drinks and tobaccos, or hotel business, is hereby declared not to be a restaurant.

In a suit to test the constitutionality of this act brought by a number of drug, department, and five and ten cents stores, for many years engaged in the business of dispensing soft drinks, ice cream, sandwiches and short orders, the federal district court for Colorado ${ }^{69}$ held that more than sufficient evidence had been introduced to establish that restaurants as defined have a substantial relation to the public health. By separating the restaurant business from other businesses within a store, said the court,

the room in which food is served ... despite the opinions of experts to the contrary ... can more readily be kept clean and sanitary; it can be kept free from dust and germ carrying flies; and as a less number of persons will enter the room than will enter the general business establishment there will be less of sneezing and coughing therein which all the experts admit may contaminate food. Persons entering a dining room are more apt to be careful of the welfare of others than they would in a general business establishment.

On this theory, the court found that this classification of businesses was neither unreasonable nor arbitrary, and therefore not in violation of the state or federal constitutions. The decision was upheld per curiam by the Supreme Court of the United States. ${ }^{70}$

\footnotetext{
${ }^{00}$ See State Milk and Dairy Legislation (W.P.A. Marketing Laws Survey, 1939).

or See analysis of laws pertaining to the sale of pharmaceutical products in Inst. of Distribution, Retailers Manual of Taxes and Regulations (ed. I940-4I). ${ }^{68}$ Cozo. Stat. ANN. (I935) c. 81, \$14.

${ }^{00}$ S. H. Kress \& Co. v. Johnson, I6 F. Supp. 5, 7 (D. Colo. 1936).

${ }^{70} 299$ U. S. 5 II (1936). This Colorado enactment, representing one form of restriction on integration of distribution lines, is discussed in Cook, Legislative Restrictions on Marketing Integration, infra this issue.
} 
A similar type of restriction is imposed on the sale of electrical appliances in Oklahoma. In interpreting a provision of that state's Corporation Act, ${ }^{71}$ requiring all public service corporations to confine themselves strictly to transaction of the business of supplying the services as defined, and forbidding them to engage, directly or indirectly, in incidental lines of business in connection with their principal activity, the Attorney General of Oklahoma held that an electric light and power company cannot lawfully buy or sell electric irons, electric fans and electric refrigerators. ${ }^{72}$

Within the group of functional limitations arising through too broad a definition of the occupation are legislative devices such as the regulation attempted by the Oregon legislature, making it a crime to practice the profession of cosmetic therapy as defined without first obtaining a certificate of registration from the State Board of Examiners. Cosmetic therapy was defined by the $\mathrm{act}^{73}$ to be

the application of the hands or of mechanical or electrical apparatus with or without cosmetic preparations, tonics, lotions, creams or clays, to massage, cleanse, stimulate, manipulate, exercise or otherwise improve or beautify the scalp, face, neck, shoulders, arms or upper part of the body, removing superfluous hair, manicuring the nails of any person, male or female, and to arrange, dress, curl, wave, cleanse, cut, singe, bleach, color or similarly treat the hair of any female.

In Illinois the legislature sought to achieve a similar result by requiring cosmetologists to obtain barber's licenses in addition to the license already obtained by them for the practice of cosmetology. This was achieved by withdrawing the occupation of hair cutting and trimming from the definition of "beauty culturist" in a statute ${ }^{74}$ defining that practice.

This type of legislation has generally met with judicial disapproval. The Oregon statute was successfully challenged by a number of hairdressers who earned their livelihood solely by hairdressing without engaging in any other practices of cosmetic therapy. Invalidation was placed on the ground that the statute arbitrarily grouped together different and unrelated callings and professions and forbade citizens from following one of them without qualifying in all others. The federal court emphasized that under the provisions of the act one might be an expert in one of the callings specified and yet be prohibited from earning a living thereby unless, in the judgment of the Board of Examiners, he was qualified to practice all of the other callings in which he might not be in the least interested. ${ }^{75}$ As a result of this decision, the Oregon law now provides for four classes of operatorshairdressers, cosmetologists, electrologists and permanent wavers-and for the issuance of a separate license to each. ${ }^{78}$. The Illinois act was also declared invalid, ${ }^{77}$

${ }^{71}$ Okta. Stat. (Harlow, 1936) \$\$9725, 9726.

${ }^{2}$ Op. OKLA. Atry. Gen., Aug. $x$, 1935. Contrast the Kansas judicial attitude toward a similar statute of that state, discussed in Cook, supra note 70 .

74 Ill. Laws 1929, p. 194, \$18.

${ }^{75}$ Baker v. Daly, 15 F. (2d) 88I (D. Ore. 1926).

${ }^{78}$ ORE. CODE ANN. (1930) $\$ 68.704$. Other statutes make similar provision for the division and separation of functions. Cas. Gen. LAws (Decring, 1939) act 1755; N. M. StAT. ANN. (Courtright, Supp. 1938) \$\$123-102-123-104; Wis. STAT. (1939) \$\$159.0I-159.16.

${ }_{77}$ Banghart v. Walsh, 339 Ill. 132, 140, 171 N. E. 154, 157 (1930). 
the restrictions having been found to be totally unrelated to the public health or welfare. By this act, the Illinois court held, the legislature attempted to require persons desiring to engage solely in cutting and trimming women's hair "to spend 1,248 hours in a school or college of barbering and two and one half years as an apprentice in a barber shop learning to shave men and trim their whiskers." Though a similar view was expressed by the Supreme Court of Minnesota, ${ }^{78}$ its present law ${ }^{79}$ now reads:

anyone or any combination of the following practices when done upon the head and neck for cosmetic purposes . . . constitutes the practice of barbering within the meaning of the act: to shave, trim the beard, cut or bob the hair of any persons of either sex.... This is exactly the type of statute which the Oregon legislature sought to avoid after the decision in the Baker case.

Then, there are the many licensing statutes covering contractors, plumbers and others engaged in the building trades or professions which are defined so broadly that one engaging only in building houses must know how to build sewers, highways, skyscrapers and bridges. Engineers specializing in electrical or other fields may be required to show proficiency as sanitary engineers, etc. The New Mexico contractors' law ${ }^{80}$ defines contractor to include persons

other than those engaged in highway or railroad construction, who either for a fixed sum, price, fee, percentage or other compensation, other than wages, undertakes . . . to construct, alter, repair, add to or improve any building, excavation or other structure, project or improvement other than to personalty....

Exceptions are provided for in this act, but the general definition still covers almost every type of contracting. In Illinois a bill was introduced in the state legislature to compel licensing of painters and to prohibit any painting, even of one's own kitchen, except by licensed painters. Although the bill did not pass it is illustrative of the type of statutes countenanced by legislative control through so broad a definition of the scope of occupational classifications. ${ }^{81}$

In the third type of functional limitation-the restriction seeking to prevent control of knowledge and scientific experience by unlicensed management or ownership-is a New York statute ${ }^{82}$ which requires that

every pharmacy shall be owned by a licensed pharmacist, and every drug-store shall be owned by a licensed druggist; and no copartnership shall own a pharmacy unless all the partners are licensed pharmacists, and no copartnership shall own a drug-store unless all the partners are licensed druggists....

Similar statutes have been enacted in several states, and upheld by the lower courts in those jurisdictions ${ }^{83}$ on the theory that corporations are generally forbidden to

${ }^{78}$ Johnson v. Ervin, 205 Minn. 84, 285 N. W. 77 (1939); see also Keith v. State, II Kan. 834, 212 Pac. 871 (1923); Lane v. State, 120 Neb. 302, 232 N. W. 96 (1930); of. State v. Leftwich, I42 Wash. 329, 253 Pac. 448 (r927).

${ }^{70}$ MinN. STAT. (Mason, I940) $\$ 5846-2$.

${ }^{80}$ N. M. Laws 1939, c. 197.

${ }^{81}$ T. N. E. C. Hearings, supra note 53 , No. II, at 5255. ${ }^{82}$ N. Y. EDuc. LAw, art. 5I, \$1354 (2).

${ }^{83}$ In re Hauges, 140 Misc. 8II, 252 N. Y. Supp. 8I (I93I); Liggett v. Baldridge, 22 F. (2d) 993 (E. D. Pa. 1927). 
engage in the practice of the learned professions. These courts argue that no one today would question the reasonableness of a statute requiring practicing physicians to be licensed by the state. In the words of a New York court: ${ }^{84}$

Can it not be said with equal reason that a license should be required of the proprietor of a pharmacy who is 'responsible for quality and potency of the drugs and chemicals which the physician prescribes to effect a cure? Is it not reasonable that the State should have some control over the man whose responsibility it is to employ men and women of expert knowledge to compound the prescriptions of a physician? If we license the physician, should we not license him who is largely responsible for putting the physician's advice into effect?

But the view followed by most courts ${ }^{85}$ was expressed by Mr. Justice Sutherland ${ }^{80}$ in holding a similar Pennsylvania statute ${ }^{87}$ invalid on the ground that the act created unreasonable and unnecessary restrictions upon private business, public interest being already amply protected by the laws requiring that only registered pharmacists can compound prescriptions and by the stringent provisions preventing the possession or sale of any impure drug or any drug below the standard of strength, quality and purity as determined by the recognized pharmacopeia of the United States. It was argued, therefore, that mere stock ownership in a corporation owning and operating a drug-store could have no real or substantial relation to the public health.

Although the proponents of this type of legislation were unsuccessful in their attempt to protect the registered druggists and pharmacists from the encroaching chain drug companies, the proponents of legislation to protect the optometrists have been successful in achieving these limitations, not so much through legislation as by judicial interpretation of the existing optometry statutes. In Philadelphia, owners of a certain department store, not licensed to practice optometry, were restrained from leasing, renting or operating in any manner whatsoever an optical or optometry unit within the store, even though the opticians and optometrists employed by the store had fully complied with all laws regulating the practice of optometry. ${ }^{88}$ On the theory that optometry is a profession, the court argued that all rules applicable to professions should apply, saying:

... a licensed practitioner of a profession may not lawfully practice his profession among the public as the servant of an unlicensed person or a corporation. . . . A corporation as such cannot possess the personal qualities required of a practitioner of a profession. ... The learning and the ethical standards required for that work, and the trust and confi-

\footnotetext{
${ }^{84}$ In re Hauges, supra note 83 , at 814,252 N. Y. Supp. at 85.

${ }^{85}$ Pratter v. Lascoff, 261 N. Y. 509, 185 N. E. 716 (1933); State v. Peoples Drug Stores, 36 Del. 120, 172 Atl. 258 (I934). For application of such laws to dentists, see Iowa v. Bailey Dental Co., 211 lowa 781, 234 N. W. 260 (I93I); Painless Parker Dentists v. Bd. of Dental Examiners, 216 Cal. 285, 14 P. (2d) 67 (1932).

${ }^{86}$ Liggett v. Baldridge, 278 U. S. 105 (1928). $\quad{ }^{87}$ PA. STAT. (Supp. I928) \$\$9377a-r, 9377a-2.

${ }^{88}$ Neill v. Gimbel Bros. Dept. Store, 330 Pa. 213, 219-220, 199 Att. 178, 181-182 (1938); sec MeMurdo v. Getter, 298 Mass. 363 , ro N. E. (2d) 139 (1937). See also Seifert v. Buhl Optical Co., 276 Mich. 692, 268 N. W. 784 (1936); Beck v. Goldman, 142 Kan. 881, 5I P. (2d) 995 (r935); State v. Kindy Optical Co., 216 Iowa 1157,248 N. W. 332 (r933); Eisenmuth v. Buhl Optical Co., I15 W. Va. 776, x78 S. E. 695 (1934).
} 
dence reposed in optometrists by those who employ them, cannot be dismissed as negligible or as not transcending the requirements of an ordinary trade.

On the other hand, a similar Missouri statute was interpreted to cover only persons who practiced either on their own behalf or as employees of another, and not persons operating through the agency of properly licensed optometrists. ${ }^{89} \mathrm{Ad}-$ hering to the doctrine established by the Supreme Court of the United States in the Liggett case, the Missouri and other courts ${ }^{90}$ have proceeded on the basis that, though the science of optometry may require much preparation and skill, it is not one of the learned professions and certainly not more learned than the profession of druggists and pharmacists. The contention is pressed that there should be no protection given to optometrists except that which may apply to any ordinary business, trade or occupation. The courts holding this view have considered, but have declined to adopt, the doctrine of agency. It is immaterial, they argue, whether licensed optometrists practice the profession on their own behalf or whether they are employed by other optometrists, by non-optometrists or by corporations, the sole legislative intent being that no person shall be examined or have glasses prescribed or prescriptions filled by one unless he is duly licensed as required by statute. Nonetheless, the trend of the decisions in the optometry cases, even without legislative sanction, ${ }^{01}$ appears to be in the direction of the decision rendered in the Neill case, and away from that in the Liggett case, on the ground that the public welfare requires the practice of optometry to be kept on a high plane of professional ethics, standards and scientific learning. That a greater public interest is more manifest in the protection necessary to the practice of optometry is hardly tenable, if for no other reason than that an error, however slight, committed by an optometrist can be corrected, whereas one committed by a druggist may be fatal. The optometrists, however, are being blessed by the courts with protection of professional status, while the business of the druggist or pharmacist continues to be considered as just another ordinary trade.

The last type of functional limitation outlined above is that which is directed against certain business practices. A New York court, in construing the scope and application of the New York insurance laws, held not to be a contract of insurance a watchmaking company's agreement with each customer to replace a watch of like character if the watch purchased was lost through theft or burglary. ${ }^{92}$ Contrariwise, an Ohio court held that an auto supply company in that state must comply with all of the licensing laws applicable to insurance when it engages in a

${ }^{\text {Bo }}$ State v. Gate City Optical Co., 339 Mo. 427, 97 S. W. (2d) 89 (x936).

${ }^{\circ 0}$ Dvorine v. Castleburg Jewelry Co., I7o Md. 661, I85 Atl. 562 (1936); Jaeckle v. L. Bamberger \& Co., IIg N. J. Eq. 126, I81 Atl. I8I (1935) affd, 120 N. J. Eq. 201, I84 Atl. 520 (1936); Ga. Board of Examiners v. Friedman's Jewelers, Inc., 183 Ga. 669 , I89 S. E. 238 (I937). See also Sage and Allen Co. v. Wheeler, II9 Conn. 667, I79 Atl. I95 (r935); State v. Gus Blass Co., I93 Ark. II59, ro5 S. W. (2d) 853 (1937).

${ }^{01}$ However, Iowa CODE (I939) \$2438.3 expressly classifies optometry as one of the learned professions, placing it in the same category with medicine, surgery and dentistry.

${ }^{22}$ Ollendorf Watch Co. v. Pink, 253 App. Div. 73, 300 N. Y. Supp. II75 (1937). 
practice of guaranteeing to replace purchased tires for defects of whatever character. The Ohio court said ${ }^{93}$

We are unable to discern any essential difference in the character and effect of the various forms of agreement of indemnity.... Such constitutes an undertaking to in. demnify against failure from any cause. ... It is substantially an unconditional promise of indemnity, and that is insurance.

\section{Restrictions as to Time}

The early restrictions on the opening and closing hours of businesses were based on the state's power to regulate nuisances in the interest of the public welfare. Under this power an ordinance of San Francisco prohibiting washing and ironing in public laundries from ten in the evening to six in the morning was upheld by the Supreme Court of the United States ${ }^{94}$ in 1885 . Later, an ordinance of Butte, Montana, regulating the opening and closing hours of persons engaged in the operation of pawnshops, second-hand stores and junk shops was upheld by the Supreme Court of Montana as a reasonable exercise of the state's police power. ${ }^{05}$ Sustainment of a similar ordinance adopted by Louisville, Kentucky, followed. ${ }^{00}$ The sale of jewelry by auction was successfully restricted under a New York statute which provided that all sales of goods by public auction in the City of New York must be made in the daytime, "between sunrise and sunset."97 The opinion that the sale of soft drinks may lead to the sale of drinks "not exactly soft in nature" was given as the reason for enforcing an Oregon law prohibiting the sale of soft drinks between the hours of midnight and five in the morning. ${ }^{98}$ Pool parlors and billiard rooms have been subjected to similar restrictions, ${ }^{90}$ and in Ig08 an Ohio statute providing for the closing of barber shops on Sundays was upheld as a valid regulation of that industry. ${ }^{100}$

For a period of over two decades legislative attempts to regulate the opening and closing hours of barber shops during week days unsuccessfully sought judicial inclusion within the proper exercise of the state's police power. In 1926, the City of Atlanta, Georgia, adopted an ordinance providing that all barber shops in the city should be closed during week days at 7:00 P.M. and on Saturdays at 9:00 P.M. The City of Laramie, Wyoming, adopted a similar ordinance, and ordinances of like character were adopted in cities in Louisiana, Mississippi, California, Washington and Minnesota. All of these regulations were declared invalid as being in violation of the due process clauses of the state and federal constitutions. ${ }^{101}$ Many

${ }^{03}$ State v. Western Auto Supply Co., 134 Ohio St. 163, 171, 16 N. E. (2d) 256,259 (1938).

${ }^{24}$ Barbier v. Connally, Ir3 U. S. 27 (I885). See also Loon Hing v. Crowley, I13 U. S. 703 (1885).

${ }^{0 x}$ City of Butte v. Paltrovich, 30 Mont. 18, 75 Pac. 521 (1904).

${ }^{06}$ Hyman v. Boldrick, 153 Ky. 77, 154 S. W. 369 (1913).

${ }^{97}$ Biddles v. Enright, 239 N. Y. 354,146 N. E. 625 (1925). See also Clein v. Atlanta, 164 Ga. 529, I39 S. E. 46 (1927).

${ }_{08}$ Churchill v. Albany, 65 Ore. 442 , 133 Pac. 632 (1913).

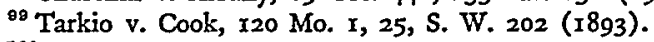

${ }^{100}$ Stanfeal v. State, 78 Ohio St. 24,84 N. E. 419 (1908). For other cases, see Anno. (1928) 55 A. L. R. 242 .

${ }^{102}$ Chaires v. City of Atlanta, 164 Ga. 755 , 139 S. E. 559 (1927); Newman v. City of Laramie, 
strong dissenting opinions, however, argued in favor of the ordinances on the ground of regulating the hours of labor for barbers. To limit the hours of labor that a barber may work each day, it was contended, is within the police power of the state, especially when there is urgent need to protect the "one-man shop against the evils arising from the (three shift) chain and all night barber shops."102

In I927, a bold New Jersey court adopted the minority view to uphold an Atlantic City ordinance requiring barber shops to close at 9:00 P.M. on Saturdays and at 8:00 P.M. on week days. The court felt that ${ }^{103}$

... to allow barber shops to remain open to the public at all hours of the night might well be regarded as rendering ready and adequate inspection inconvenient or difficult or even impossible, and consequently detrimental to public health. Such considerations are for fair determination of the municipal authorities, and we cannot say that the regulation in the instant case is unreasonable.

In commenting on this logic, an Ohio court, upholding a similar ordinance of Zanesville, said:104

We do not regard this reasoning as "specious." ... Barber shops, which are usually respectable, and operated by law-abiding citizens, may become lounging places for the idle and dissipated, and so a menace to minors, and often in our cities the barber shop in front may be a blind for a den of thieves, professional gamblers, gangsters and racketeers behind.

And, in its zeal to uphold the ordinance, the court continued:

This situation is well known, and is even a matter of common knowledge among policemen in our large cities. At the time a certain policy racket man and former bootlegging beer baron was recently killed in New, York City, two of his henchmen were shot down in a midnight barber shop. ... If barber shops may run at all times of the night the number of vicious places of this character will inevitably be augmented. . . . We are of the opinion that the provisions of the ordinance under inquiry are neither unreasonable, discriminatory, arbitrary, nor capricious, and that they bear a "real and substantial relation" to the object sought to be attained; namely, public health, morals, and safety.

A similar ordinance enacted by the City of Cincinnati was upheld by the federal district court for the Southern District of Ohio. ${ }^{105}$ The most recent enactment is

40 Wyo. 74, 275 Pac. 106 (I929); City of Alexandria v. Hall, I7I La. 595, I3I So. 722 (r93I); Knight v. Johns, I6I Miss. 519, 137 So. 509 (I932); Ganley v. Claeys, 2 Cal. (2d) 266, 40 P. (2d) 817 (I935); Patton v. City of Bellingham, 179 Wash. 566, 38 P. (2d) 364 (1935); Pavlik v; Johannes, 194 Minn. 10, 259 N. W. 537 (1935).

${ }^{102}$ See Patton v. City of Bellingham, supra note ror.

${ }^{103}$ Falco v. Atlantic City, 99 N. J. L. I9, 2I-23, I22 Atl. 610, 6II (I924).

104 Wilson v. City of Zanesville, 130 Ohio St. 286, 295-296, I99 N. E. I87, 193-195 (1936). Judge Jones, dissenting, said: ". . . one reading the majority opinion may well wonder what the real crux of this controversy between the city and the barber is. ... This ordinance may be such that would receive the approval of a Soviet or Fascist regime. . .."

${ }^{105}$ Feldman v. City of Cincinnati, 20 F. Supp. 531 (S. D. Ohio 1937). Contra: Opinion of the Justices, 300 Mass. 6r5, 14 N. E. (2d) 953 (I938); Oklahoma City v. Johnson, I83 Okla. 430, 82 P. (2d) 1060 (1938). 
an Indiana law, ${ }^{106}$ as yet uncontested but similar in many respects to other barbering codes upheld in several states. ${ }^{107}$ Its gist is that

the Board of Barber Examiners shall have power to approve and, by official order, to establish the days and hours when barber shops may remain open for business, whenever agreements fixing such opening and closing hours have been signed and submitted to the Board by any organized and representative group of barbers, and after such agreements have been signed by at least eighty per cent of the barbers licensed by said board and operating in any trade area of the state, and shall have the power to investigate the reasonableness and propriety of the days and hours fixed by such agreements.

Although the numerical weight of judicial authority continues to be against the validity of such restrictions, the trend is in the opposite direction on the ground that reasonable business hours enable municipal officers to fix a definite time within which sanitation inspectors may readily and adequately perform their duties. It is also said that public health and safety are safeguarded by forcing the shops to close at certain hours to prevent fatigue on the part of barbers wielding "keen edged razors and sharp scissors"; and that by keeping respectable business hours "crime and nuisance would be appreciably eliminated."

Thus the restrictions accumulate in the name of sanitation and public health and welfare. And the owner of the one or two chair barber shop is limited further in his competition with the larger and more elaborate shops. The opportunity he has of getting certain patronage in the evenings and on Sundays is eliminated, even though the majority of the inhabitants residing within the immediate vicinity of the shop are employed or otherwise occupied and unable to obtain their hair-cut, shave or manicure within the prescribed hours. Restrictions such as these may provide employment for a great many barber inspectors but they certainly accomplish very little to help the plight of the thousands of small barber shops throughout the country. ${ }^{108}$

\section{Restrictions as to Place}

Aside from the many detailed and exacting zoning provisions imposed by states and municipalities on the location of one's business, trade or occupation, numerous other devices have been employed under the guise of police power and revenue raising to prevent not only out-of-state but out-of-town and county businesses from competing with local merchants. It is this type of marketing barrier which, because of the directness of its geographical limitations against "outsiders," most closely resembles the so-called interstate trade barrier. These are the laws enacted by states, municipalities, villages and townships which either on their face or in practical

${ }^{100}$ Ind. Laws 1939, c. x08, $\$ 4$.

${ }_{10 z}$ The constitutionality of the master barber codes' hour as well as price regulation is discussed at a Iater point in this article.

${ }^{108}$ According to the U. S. Bureau of Labor Statistics, in 1935 there were 125,455 barber shops in the United States, their annual receipts for all services rendered during that year amounting to nearly $\$ 230,000,000$, or approximately an $\$ 1800$ average for each shop. Out of this the barber, whether operating a large or small shop, had to pay salaries, rent, supplies, miscellancous expenses, and a return on his investment in establishing himself in business. (1939) 48 MontmLX LAB. REv. 1287. 
effect operate to the disadvantage of persons, products and services coming from other communities and to the advantage of local residents, products and businesses.

Hawkers and peddlers have frequently been restricted in their activities by municipalities. Many of these restrictions have been declared invalid under either the due process, equal protection or interstate commerce clauses. ${ }^{109}$ But other courts have held that classifications between residents of a city and non-residents are fully justified where the circumstances and conditions are different. The Supreme Court of South Carolina upheld a Sumter ordinance exacting an annual license fee of \$25 from local bakers, while doubling this fee for bakeries with an established place of business out of the city and selling or delivering their product within the city of Sumter. The court said:110

. . . unless there is evidence to show that the imposition of a higher license on nonresidents was unreasonable, capricious or confiscatory, no provision of either the constitution of the state or of the United States was violated.

So also, the Florida high court, in placing the I. Miller Shoe Company within the classification of businesses subject to a Florida itinerant merchants tax law, ${ }^{111}$ found $^{112}$

... little constitutional difficulty to be encountered in a legislative attempt to single out for special taxation that class of merchants whose business is presumptively so profitable that they can make sufficient profit in three months to pay twelve months' rent, and enjoy a nine months' vacation from business on the profits of the three.

The I. Miller Shoe Company is a nationally advertised company. Its store in Miami had a stock valued at $\$ 2,000$ plus fixtures and the company held a lease on the premises from year to year.

An ordinance adopted by Lynchburg, Virginia, levies a tax

On every person, firm or corporation engaged in towel service or the renting or furnishing of towels for compensation, $\$ 25$ per annum. ... On every person, firm or corporation (other than a laundry or dry-cleaning establishment located in the City of Lynchburg, paying regular laundry or dry-cleaning taxes in the City of Lynchburg) engaged in soliciting general laundry or dry-cleaning work, including towel or laundry service, or the renting or furnishing of towels and linens for compensation, where said person, firm or corporation does the laundry or dry-cleaning work thereon outside of the city, or has it done outside of the city, $\$ 300$ per annum, not prorated.

This measure was declared to be a valid exercise of the municipality's taxing power." Emphasizing that "classifications are to be sustained whenever there is

${ }^{100} \mathrm{O}^{\prime}$ Connell v. Kontojohn, 131 Fla. 783,179 So. 802 (1938), declaring invalid an ordinance imposing a license tax of $\$ 250$ on each truck wagon operated in Pensacola, Florida, by wholesale bakers located outside the city. See also Ex parte Smith, roo Fla. I, I28 So. 864 (1930); Ward Baking Co. v. City of Fernandia, 29 F. (2d) 789 (S. D. Fla. 1928); Hair v. Humboldt, I33 Kan. 67, 299 Pac. 268 (r93r).

${ }_{110}$ American Bakeries Co. v. City of Sumter, I73 S. C. 94, I74 S. E. 919 (I934), cert. denied, 293 U. S. 523 (I934).

111 Fla. Laws 1929, c. 14528 .

${ }_{112}$ Greenleaf \& Crosby Co. v. Colenan, II7 Fla. 723, 745-746, I58 So. 421, 429 (I934).

113 Richmond Linen Supply Co. v. Lynchburg, x6o Va. 644, I69 S. E. 554 (1933), aff'd, 291 U. S. 64I (1934). See also Vaugh v. Richmond, I65 Va. 145, I8I S. E. 372 (1935). 
any fair basis for them," the Virginia Supreme Court found the discrimination a fair basis for classification on the oft-repeated proposition that local businesses are otherwise locally taxed, directly and indirectly, while the non-resident wholly escapes such taxation. The court argued that if the taxes in question were equalized, the local merchants would have cause for complaint as they are at the same time required to pay property and water taxes which are not levied against their out-oftown competitors. The court concluded that

Experience has shown that these nation-wide corporations sometimes destroy the business of local competitors, and in many communities are conduits rather than reservoirs of capital. This seems to be the basis of chain store legislation. Its wisdom is not for the courts.

But the court added, rather apologetically:

Those underlying principles which have brought it [the ordinance] about apply in the instant case. Public policy is with the city.

Classifications such as these, based solely on residence or non-residence, are obviously arbitrary and unreasonable. The state-wide merchant pays taxes in his own community comparable to property, water and other taxes on local merchants. In addition, they are discriminatory and restrictive of competition through their establishment of provincial tariffs for the protection of local monopolies. The trend, however, appears to be toward greater licensing tax differentials levied by municipalities upon non-residents. It is likely to continue if the courts persist in the dilution of the due process and equal protection clauses.114

\section{Price Restrictions}

Finally to be considered under the relation of persons in business to each other is legislation authorizing price-fixing within different types of distributive occupations. Since the decision of the Supreme Court of the United States validating the New York milk control act, ${ }^{115}$ many states have adopted price-fixing statutes affecting a wide variety of products and businesses. ${ }^{118}$ That decision, however, has given rise to a considerable amount of confusion as to just how far a state may proceed with price-fixing legislation. The Supreme Court, prior to the Nebbia case, had quite generally adhered to the view that price-fixing by the state was valid only when applied to businesses affected with a public interest. ${ }^{117}$ But the Court, in the Nebbia case, indicated ${ }^{118}$ that

\footnotetext{
114 Campbell Baking Co. v. Harrisonville, 50 F. (2d) 670 (C. C. A. 8th, I93I); Jewel Tea Co. v. Troy, 80 F. (2d) 366 (C. C. A. 7th, 1935); Williams v. Bowling Green, $254 \mathrm{Ky}$. II, 70 S. W. (2d) 967 (1934). See also Notes (193I) 5 So. Cal. L. Rev. I64, (I937) 85 U. op PA. L. Rev. 323, (I934) 43 YAIE L. J. I3I4; Note, The Legislative Monopolies Achieved by Small Business (1939) 48 YALE L. J. 847. Municipal power in this and other regards is carefully analyzed in McIntire and Rhyne, Municipal Legislative Barriers to a Free Market, infra this issue.

${ }_{115}$ Nebbia v. New York, supra note 5.

${ }^{110}$ In addition to special price legislation, 44 states have adopted resale price maintenance acts and 25 states have adopted sales-below-cost legislation. See State Price Control Legistation (W.P.A. Marketing Laws Survey, 1940).

${ }^{117}$ New State Ice Co. v. Liebmann, supra note 6.

${ }^{118}$ Nebbia v. New York, supra note 5, at 536 .
} 
there is no closed class or category of businesses affected with a public interest, and the function of courts in the application of the Fifth and Fourteenth Amendments is to determine in each case whether circumstances vindicate the challenged regulation as a reasonable exertion of governmental authority or condemn it as arbitrary or discriminatory. . . B But there can be no doubt that upon proper occasion and by appropriate measures the state may regulate a business in any of its aspects, including the prices to be charged for the products or commodities its sells.

As a result of this language, it has been argued that the " 'magic formula' affected with a public interest" has been repudiated and that price-fixing is now placed with other types of restrictions on the use of private property as one which is invalid only if arbitrary in its particular application. ${ }^{119}$ On the other hand, there appears no justification for the conclusion that the Nebbia case is authority for legislative pricefixing in all commodities. "What the legislative power may be in a given case regarding any industry we do not undertake to say. Sufficient unto the day is the power thereof."120

Legislative attempts to exercise price-fixing authority have in any event taken on some interesting aspects. Several states have enacted statutes designed to fix the prices at which a barber may sell his services. Such legislation, in general, authorizes an administrative agency to establish minimum prices for barber work. A usual restriction on the authority of the board requires that it conduct an investigation for the purpose of determining that such established prices are just and reasonable. Ordinarily price levels are submitted by organized groups composed of seventy-five percent of the barbers of a particular governmental unit within the state, such as a county or judicial district. A legislative finding of an economic emergency is usually set forth in the statute. ${ }^{121}$

This type of legislation has received rather severe treatment at the hands of state courts. An examination of the cases reveals varying grounds for the invalidation of such statutes. An Iowa court took the view that the act violated personal liberty in that it restricted the contractual rights of individual barbers. ${ }^{122}$ In Florida a similar statute was found unconstitutional as a denial of equal protection and due process and as an improper restraint on freedom of contract. ${ }^{123}$ The courts of Tennessee and Alabama were not inclined to look upon the barbering business as one affected with a public interest and, accordingly, invalidated the legislation in each state. ${ }^{124}$ Both courts attempted to distinguish the Nebbia case by reasoning that the

210 Doskow, Historic Opinions of the United States Supreme Court (I935).

${ }^{120}$ Darweger v. Staats, 267 N. Y. 290,308 , 196 N. E. 6r, 67 (r935). See also Doubleday, Doran \& Co. v. Macy \& Co., 269 N. Y. 272, 199 N. E. 409 (1936).

${ }^{121}$ See note 108, supra.

${ }^{122}$ Duncan v. City of Des Moines, 222 Iowa 218,268 N. W. 547 (1936). It should be noted that the decision in this case was based on the authority of Adkins v. Childrens Hospital, 26I U. S. 525 (1922), specifically overruled by West Coast Hotel Co. v. Parrish, 300 U. S. 379 (1937). Furthermore, the statute made no attempt to fix wages of employees.

${ }^{123}$ Fulton v. Ives, 123 Fla. 401, 167 So. 394 (1936); but see Miami Laundry Co. v. Florida Dry Cleaning \& Laundry Bd., infra note 128 , holding valid the Florida laundry and dry cleaning act.

${ }^{124}$ Mobile v. Rouse, 233 Ala. 622, 172 So. 266 (1937); State v. Greeson, Board of Barber Examiners v. Melton, I74 Tenn. I78, 124 S. W. (2d) 253 (1939). 
right of a state to regulate barbers is not absolute and must be exercised in a reasonable manner so as not to interfere with private rights.

On the other hand, the Louisiana court, when presented with the question, made much of the economic chaos existing in the milk industry in the New York milk shed area. A similar situation is said to have existed in the barber trades in many states prior to the adoption of these statutes, ${ }^{125}$ thus affording factual basis for the legislative findings to this effect. With this background the Louisiana court, after having first declared the barbering statute of that state unconstitutional, reversed itself on rehearing and permitted the statute to stand. The opinion followed the Nebbia decision, finding the act a legitimate exercise of the police power and not unreasonable or arbitrary. There was included in the law a legislative determination that low prices made it impossible to support and maintain reasonably safe and healthful barbering services to the public. ${ }^{128}$ The result was declared by the legislature to be a menace to the health, welfare and reasonable comfort of citizens of the state and one which tended toward the transmission of disease. In addition, the legislature had declared an acute economic condition to exist, resulting in great disparity between the prices of barber work and other commodities. This condition was found to be largely instrumental in destroying the purchasing power of barbers in industrial and sanitary products essential to the operation of business, thus impairing and injuring the public health and safety.

But barbering is by no means the only business which has been subjected to price-fixing legislation of this type. Consider, for instance, a Florida statute setting up a price-fixing arrangement for dry-cleaning and laundry businesses. ${ }^{127} \mathrm{Here}$, again, there was a legislative finding of evils prevalent in the industry. The Florida Supreme Court, although it had declared invalid the price-fixing provisions of the Barbering Code, sustained this legislation, ${ }^{128}$ arguing that the liberty of contract and the right to use property must be determined in the light of prevailing social and economic conditions. The view taken was that when conditions in a business become such that the welfare of the public will not be adequately protected by unrestricted competition, it is within the police power of the state to remedy the evil. The court indicated that if it can be shown that ruinous or chaotic conditions are extant within an industry, or that the economic existence of large numbers of people is being threatened, then the legislature may step in and prescribe regulations to correct the alleged or threatened abuses. An interesting and, perhaps, plausible contention was advanced by the minority to the effect that if the state can fix prices for the cleaning and laundry industry, it may do the same for clothing stores, tailors, drug-stores, grocery stores, etc.

\footnotetext{
${ }^{125}$ Compare note 108, supra.

${ }^{126} \mathrm{Bd}$. of Barber Examiners of Louisiana v. Parker, Igo La. 214, r82 So. 485 (1938); cf. State v. Chisesi, supra note 47 , holding the farm produce act invalid, even though it made no provision for price fixing of farm products.

${ }^{127}$ Fla. Laws 1937, c. 17894 .

${ }^{128}$ Miami Laundry Co. v. Florida Dry Cleaning and Laundry Board, I34 Fla. I, I83 So. 759 (1938). Comparc the language in Fulton v. Ives, supra note $\times 23$.
} 
Unquestionably, legislative price-fixing has yet to prove its efficacy in curing economic ills. It is worthy of note that in the Parker case ${ }^{129}$ both sides agreed to a stipulation to the effect that, owing to the economic status of his clientele, the defendant could not earn a livelihood by charging the prices fixed by the board but could do so by charging lower prices. Inspectors had found that the defendant had satisfactorily complied with all sanitary requirements, and this at a time when he was charging less than the minimum price fixed. Anyone acquainted with the processes of milk distribution knows that the industry has in the past operated on an unsound economic basis. Milk control legislation was designed to correct this evil and the United States Supreme Court recognized it as such. It has not been demonstrated, however, that legislative price-fixing in the milk, any more than in any other, industry is a satisfactory solution to the problems of either the producer or the consumer. In the City of Washington, D. C., there is no price-fixing in the mill industry. Competition in the sale of milk is relatively free and unfettered. Virginia, on the other hand, has a Millk Commission with power to fix prices. An editorial from the Washington Post for March 4, I94I, reprinted in the footnote, ${ }^{130}$ illustrates at least some of the problems involved under legislative determination of retail prices.

Reference has been made earlier to the existence of a relatively new type of licensing legislation apparently designed, in a degree at least, to cloak with legislative sanction privately-created price controls in the automobile-selling field. To appraise this development a bit of background is essential. The automobile dealer occupies a rather unique position among retail merchants in that his business is virtually under complete control of the manufacturer. This situation is attributable to the superior bargaining position of the manufacturer which enables the latter to impose extremely difficult terms on the dealer under the threat of withdrawal of "franchise." Exclusive dealing arrangements are integral parts of manufacturerdealer contracts in the handling of both vehicles and parts, accessories and supplies. Further restrictions on the dealer include territorial limits placed on sales, manufacturer-supervised accounting systems, display rooms, advertising, and "forced sales." The existence of such practices is a severe strain on the operation of the competitive

$120 \mathrm{Bd}$. of Barber Examiners of Louisiana v. Parker, supra note 126.

130 "Millx Prices

"Retail milk price fixing is a hangover from the days of NRA, when any measure was seized on to preserve the shaky status quo. But methods of distributing milk have brought such economies that the price structure has been naturally undermined. Already Washington is experiencing the benefits of such simple innovations as the paper container, which makes price reduction sound by eliminating the loss of bottles, and the two-quart sale, which accomplishes the same result by reducing overhead. A fixed retail price, however, effectively prevents such innovations, because the consumer, if he must pay the same price, demands his milk in glass bottles a quart at a time.

"It is true in milk as in everything else that a lower price would bring more trade if the enterprising distributor could reduce his prices through his economies. But under the present system, experimentation is penalized. Hence the old methods, and the old prices, remain. If the Virginia Milk Commission can find any good way to apply efficient methods to the maximum benefit of the consumer's pocketbook without abandoning its price-fixing policy, all right. If the commission can't, then it looks very much as if the policy is a barrier to progress." 
principle and two agencies of the Federal Government have intervened in an effort to relieve hardships upon dealers as well as upon the automobile consumer. ${ }^{131}$

Activities of dealers themselves, however, have not been entirely irreproachable. An investigation by the Federal Trade Commission ${ }^{132}$ reveals that dealers in many cities and states have, without legislative sanction, engaged through associations in the promotion of plans which appear to have as their main object the restriction of price competition among their members. These plans have been developed largely for the purpose of combating the deleterious effects on the automobile market of the ever-increasing number of used cars. In actual operation, they appear in a rather sinister garb, involving secret code numbers given deals, secret telephone numbers given appraisal bureaus and penalties levied on dealers failing to comply with rules and regulations of the organization.

Examination of the new dealer licensing statutes reveals clearly a purpose to give legislative sanctity to such regulations of the industry, particularly in the matter of price control. Interesting questions may be raised with respect to the legality of parts of these statutes. ${ }^{133}$ Compare, for instance, Section $60-913$ of the Nebraska statute with Section 1315 of the Pennsylvania statute, ${ }^{134}$ declared unconstitutional in its earliest days.

The following provision is from the Nebraska act:

For the purpose of determining whether or not an applicant for a license or a holder of a license has violated any of the provisions of this law with particular regard to price discrimination and excess allowances on used motor vehicles, the administrator may authorize ... a survey to be made to determine a fair basis for allowances to be made for used cars in purchases thereof or exchanges for other new or used cars. Such survey, if made, shall be amended from time to time as market conditions change. . . . Said survey shall serve as a guide and shall in no way be binding upon any licensed dealer or salesman except for the purpose stated hereinbefore in this Act.

The Pennsylvania act provided that:

The Commission shall, within thirty (30) days from the time it is established, determine by a survey what the average sale price for used motor vehicles was for each make, model, body type and year, and shall issue orders that for the ensuing thirty (30) days no appraiser shall appraise a used motor vehicle for a greater amount.

The provision of the Pennsylvania statute was invalidated ${ }^{135}$ on the ground that the automobile business was not one affected with a public interest to such an

${ }^{181}$ In the Matter of General Motors Corporation and General Motors Sales Corporation, F. T. C. Docket No. 3152. The Antitrust Division of the U. S. Dep't of Justice has been successful in securing indictments under the Sherman Act against General Motors and certain affiliated corporations, the Ford Motor Company, the Chrysler Corporation and finance companies controlled by them. Consent decrees were entered against Ford and Chrysier who had only working agreements with finance companies. General Motors, electing to stand trial, was found guilty. U. S. v. General Motors Corp., 26 F. Supp. 353 (N. D. Ind. I939).

For a discussion of the consent decrees, see Birnbaum, The Auto Finance Consent Decree: $A$ New Technique in Enforcing the Sherman ACt (1939) 24 WASH. U. L. Q. 525. For a discussion of the relationship between automobile manufacturers and their agents, see Comment, The Antitrust Laws and the Automobile Industry (1940) 34 ILI. L. REv. 956.

132 Note 2, supra.
${ }_{135}$ Heind Motors, Inc. v. Teefy, supra note 33 .

134 The statutes are cited $i b i d$. 
extent as to justify the periodic fixing of maximum prices. The Nebraska statute, on the other hand, does not attempt to establish maximum prices as such. Instead, the "fair basis of allowance" is made a criterion or guide by which the administrator may determine whether or not a dealer is engaging in price discrimination or giving excess allowances on used cars. He then determines on the basis of the survey whether a dealer's license should be denied or revoked. This approach has a less coercive aspect, but it appears to reach substantially the same result as the Pennsylvania Act. The Nebraska statute has not, however, been challenged on the basis of constitutionality.

\section{Concluston}

No attempt has been made herein to explore exhaustively the countless number of restrictions which operate to harass the life of the small business man, regardless of his calling. But it is believed that a sufficient number of illustrations has been given to emphasize the effect on business enterprise of this series of progressive restrictions in the form of legislative restraints. Many of these restrictions cannot be justified in the name of protection of the public health, safety and welfare because they are regulatory far beyond any such requirements. Unquestionably many such statutes have been inspired and placed on the books by the activity of pressure groups with selfish motives. Many have also been prompted by a sincere desire to solve the problem of what to do with small business.

Let no one mistakenly believe that these legislative limitations have only local implications. They have a cumulative effect on our national economy as a whole. When the business activity of "the butcher, the baker, the candle-stick maker" is obstructed by unwarranted statutory obstacles, the purchasing power of the nation is vitally reduced. Whatever case may be made out for governmental supervision of large industrial units, it has little application to the situation presented here. Many of the statutes discussed are capable of being used, and many are actually being used, for the strangulation of the individual initiative of persons in lower economic levels. 